\title{
ДИСТАНЦІЙНА СИСТЕМА НАВЧАННЯ ЯК ЕФЕКТИВНИЙ ЗАСІБ ДЛЯ ЗДОБУТТЯ ОСВІТНЬОЇ КВАЛІФІКАЦІЇ МАГІСТРА МЕДСЕСТРИНСТВА В ТЕРНОПІЛЬСЬКОМУ ДЕРЖАВНОМУ МЕДИЧНОМУ УНІВЕРСИТЕТІ ІМЕНІ І. Я. ГОРБАЧЕВСЬКОГО
}

Н. I. Рега

ДВНЗ “Тернопільський держсавний медичний університет імені І. Я. Горбачевського МОЗ України”

\author{
DISTANCE LEARNING SYSTEM AS AN EFFECTIVE STEP FOR \\ REACHING MASTER DEGREE IN NURSING IN TERNOPIL STATE \\ MEDICAL UNIVERSITY BY I. YA. HORBACHEVSKY
}

\author{
N. I. Reha \\ SHEI “Ternopil State Medical University by I. Ya. Horbachevsky of MPH of Ukraine”
}

\begin{abstract}
У статті розглянуто питання впровадження дистанційної освіти для здобуття кваліфікації магістра медсестринства в Тернопільському державному медичному університеті імені І. Я. Горбачевського як один із елементів у реформуванні системи медичної освіти в Україні.
\end{abstract}

The article describes main points of distant education implementation for reaching Master degree in Nursing in I. Ya. Horbachevsky Ternopil State Medical University as an element of medical educational reformation in Ukraine.

Вступ. Підготовка, перепідготовка та підвищення кваліфікації медичних сестер є важливою складовою діяльності галузі охорони здоров'я, оскільки від рівня ї підготовки залежить якість надання медичної допомоги населенню країни. Беручи до уваги, що підготовка медичних сестер - молодших медичних спеціалістів в Україні має багаторічний досвід, більше уваги необхідно приділити якості підготовки медичних сестер кваліфікаційних рівнів “бакалавр” та "магістр”, які безпосередньо будуть брати участь у навчанні та післядипломній перепідготовці основної маси медичних сестер, а також керувати ними у практичній роботі у якості організаторів та менеджерів охорони здоров'я [1]. Велику увагу необхідно приділяти освіті медсестер на рівні світових стандартів. Сестринська справа поєднує у собі одночасно мистецтво і науку. Вона вимагає оволодіння специфічними навиками, знаннями і умінням їх практичного застосування. Процес реформування сестринської справи в даний час в Україні відбувається, але значно повільніше, ніж цього потребує суспільство. На сьогодні існує низка чинників, які об'єктивно перешкоджають успішному реформуванню сестринської справи, у т. ч. правові, організаційно-управлінські (практична відсутність організаторів сестринської справи, що володіють сучасними методами менеджменту і маркетингу, які здатні проводити експертизу якості і ефективності медсестринської допомоги у селах та містах), дефіцит медсестринських кадрів і молодшого медперсоналу, низька укомплектованість фахівцями-організаторами сестринської справи з вищою освітою - бакалаврами та магістрами, високі показники роботи за сумісництвом, відсутність диференційованого навантаження і оплати праці фахівців, які мають різні рівні освіти, наприклад головна медсестра 3 середньою спеціальною освітою і вищою медсестринською освітою. Тобто не вирішено до кінця питання 3 працевлаштуванням медичних сестер 3 вищою освітою внаслідок відсутності законодавчої бази та занадто малим $є$ перелік посад для медсестер 3 вищою освітою. Також практично відсутня моральна та матеріальна зацікавленість медичних сестер у вдосконаленні професійних знань та навичок. Наявні проблеми при влаштуванні на роботу та адаптації молодих фахівців на робочому місці. Медсестрам, як і лікарям, а можливо, і навіть більше, стають властивими синдроми емоційного вигоряння та хронічної втоми, особливо на тлі відсутності нор-

(C) H. I. Рега 
мативів навантаження та стандартів якості роботи. Однією $з$ причин $є$ також недостатня активність самих медичних сестер. Перебування десятиліттями на других ролях у медицині відучило цілі покоління медичних сестер від прагнення проявляти ініціативу щодо поліпшення медичного обслуговування пацієнтів. На практиці ж спостерігається збільшення у лікарській діяльності частки тих видів медичних послуг, які повинні здійснювати добре підготовлені медичні сестри, а сестринському персоналу часто відводиться роль технічного персоналу, яка не вимагає спеціальної медичної підготовки. Відповідно посилюється негативний вплив на якість сестринської допомоги, імідж і привабливість професії медичної сестри. Розширення самостійності медичних сестер при організації догляду за хворими та збільшення кількості і об'єму маніпуляцій при догляді за пацієнтом можна досягнути за певних умов, якими є: отримання якісної професійної освіти та відповідно адекватної їй заробітної плати, створення сучасного матеріально-технічного забезпечення робочих місць, наукова організація праці з урахуванням нових технологій у лікувально-діагностичному процесі тощо [2].

Основна частина. Виникнення глобальної мережі Інтернет стало поштовхом у створенні та розвитку навчання за допомогою нових інформаційних технологій, а також загальному розповсюдженню дистанційної форми навчання. Всесвітня павутина спричинила розвиток мережевих технологій, а також надала можливість студентам та викладачам використовувати електронні підручники, бібліотеки, зручні системи тестування та інформаційні засоби спілкування. Інтернет дозволив не тільки об'єднати всі раніше відомі інструменти навчання, але і помітно розширити їх перелік, зробивши істотний вплив на інформаційну культуру в освітньому середовищі. Сьогодні навчання засобами Інтернету все частіше розглядається як альтернатива традиційній освіті, яка дозволяє студентові отримати глибокі знання. Одним з видів навчання за допомогою мережі Інтернет є дистанційна форма навчання [3].

Дистанційне навчання - це форма отримання освіти, при якій в освітньому процесі використовуються кращі інноваційні засоби та форми навчання, що грунтуються на комп'ютерних і телекомунікаційних технологіях [4]. У дистанційному навчанні перевага віддається самостійній роботі студента. Суб'єкт і об' єкт навчання мають можливість здійснювати навчальну діяльність у зручному для себе місці, за попередньо узгодженою схемою й індивідуальним інтервальним графіком взаємодії в часі.
При дистанційному навчанні існують певні особливості, пов' язані, перш за все, з наявністю технологічних можливостей студента. Для навчання йому необхідно мати регулярний доступ до персонального комп'ютера, бажано з підключенням до Інтернету, на якому встановлена операційна система не нижче Windows 98. Навчатися можна в режимі on-line. При цьому використовуються спеціальні технології, серед яких знайшлипоширення: кейс-технології (базуються на пакетах навчально-методичних матеріалів для самостійного вивчення, контрольних завданнях і тестах контролю); телевізійні технології (базуються на замкнутих телевізійних системах із зворотним зв'язком); технології відеоконференцій (базуються на засобах забезпечення двостороннього або багатостороннього аудіовідеозв'язку на значних відстанях) та комбіновані технології [5].

Організація навчання передбачає правильно розплановані етапи засвоєння навчальної дисципліни: лекційні, практичні і лабораторні заняття, семінари, чати, форуми, виконання контрольних робіт, консультації з навчальних дисциплін, самостійна робота тощо. Основною формою отримання знань $є$ самостійна робота. У процесі навчання важлива роль надається методиці оцінювання отриманих знань та їх контролю за етапами навчання. Заключна стадія навчання передбачає повторювання й узагальнення. Вивчивши європейський та американський досвід проведення дистанційної форми навчання та заручившись підтримкою MO3 України, на базі Тернопільського державного медичного університету імені I. Я. Горбачевського відкрито центр дистанційного навчання для медсестер-бакалаврів та медсестер-магістрів [6]. Тривалість навчання медсестер-магістрів становить 2 роки (4 семестри).

На базі центру підготовлена платформа дистанційного навчання, інтегрована з Web-порталом університету. Для відповідного напрямку підготовки фахівців з використанням технологій дистанційного навчання розроблений та затверджений навчальний план. Реєстрація абітурієнтів, які бажають навчатися за дистанційною формою, прийом документів, вступних іспитів та співбесіди здійснюються через Web-портал університету. На порталі 3-ма мовами (українською, російською, англійською) представлені для користувачів 3 авторизованим доступом методичні матеріали - розклади занять та лекцій, робочі програми з дисциплін, методичні вказівки, презентації лекцій, матеріали для підготовки до лекцій і практичних занять, інструкції щодо виконання практичних навичок, електронні підручники, навчальні таблиці [7]. 
Зв'язок викладача із студентом відбувається через мережу Інтернет на порталі університету двома основними способами: перший спосіб - обмін інформацією через поштові скриньки, розміщені на Webпорталі університету; другий спосіб - зв'язок через Інтернет у системі “Skype". Кожному студенту відкрита персональна електронна поштова скринька на Web-порталі університету й надано персональний пароль та логін доступу до нього на час проходження навчання. Через дану скриньку викладач підтримує зв' язок із студентом, а також студент має змогу відправляти власну інформацію на скриньку викладача. Викладач і студент також реєструються у системі "Skype" та через встановлені Web-камери проводять спілкування і вільно обмінюються інформацією 3 навчального процесу. Цей спосіб дає можливість ідентифікації особи (студента) і збільшує швидкість обміну інформації. Напередодні (за день до початку викладання дисципліни) викладач зв'язується зі студентом шляхом відправлення необхідної інформації про методику навчального процесу 3 даної дисципліни.

Контроль якості підготовки студентів здійснюють у межах кожної дисципліни, проводять вхідний, щоденний і поточний контроль знань під час контрольних та семінарських занять. Підсумковий контроль знань включає семестрові, семестрово-модульні диференційовані заліки та іспити, а також перевідні і державні іспити. На всіх етапах контролю якості підготовки студентів використовують тестові завдання. Для дисциплін, формою контролю яких визначено іспит, передбачено контроль у формі єдиного комплексного тестового іспиту на порталі університету.

Усі оцінки, отримані студентом протягом навчального процесу, заносять в електронну базу університету "Контингент", а також у навчальні журнали по кафедрах згідно з пройденою дисципліною.

Успішно закінчився перший рік навчання магістрів 3 медсестринства у Навчально-науковому інституті медсестринства Тернопільського державного медичного університету імені І. Я. Горбачевського. Зараз в магістратурі з медсестринства на дистанційній формі навчання успішно здобувають освіту 15 вітчизняних та 4 іноземних студенти 2-го року навчання. Слід відмітити, що окрім опановування навчальних дисциплін згідно з навчальним планом, студенти-магістранти успішно працюють над написанням індивідуальної наукової магістерської роботи під керівництвом наукових керівників. На першому курсі розпочали навчання 26 вітчизняних та 8 іноземних студентів. Зростання кількості студентів свідчить, що здобуття кваліфікацій медичної сестри - магістра медсестринства $є$ необхідним на сучасному етапі, та прогнозує зростання попиту на освітні послуги з даного освітнього рівня саме на дистанційній формі навчання. Але уже зараз виник ряд проблемних питань, таких, як забезпечення сучасною навчальною літературою відповідно до затверджених освітніх стандартів підготовки магістрів з медсестринства, виділення баз проходження всіх видів практики з призначенням достатньо підготовлених керівників з практики та відповідним навчальним матеріально-технічним рівнем їі забезпечення, виділення і надання відповідного статусу центрам післядипломної освіти. Вирішення цих питань потребує значних організаційних зусиль, фінансових затрат та часу, а також необхідності створення нової нормативно-правової основи для їх запровадження. Адже без цього реформування системи медсестринської освіти може надовго загальмуватися та відповідно відтермінується наближення наших фахівців до міжнародних стандартів забезпечення якості їх навчання та рівня практичних умінь. Мережа університетських лікарень та клінік дозволить створити відповідне кадрове, навчально-методичне та матеріально-технічне забезпечення системної і послідовної клінічної підготовки майбутньої медичної сестри. Але питання їі створення, оснащення сучасною апаратурою та забезпечення висококваліфікованими кадрами теж потребує затрат часу, фінансів та значних організаційних зусиль з одночасним вирішенням проблем на законодавчому рівні. Запровадження у вищих медичних навчальних закладах новітніх медичних та педагогічних інновацій має стати основою для досягнення нової якості підготовки медсестер. Вони мають створювати мотивацію до розвитку у них таких індивідуальних якостей, як відповідальність за доручену ділянку роботи, працездатність та працьовитість $з$ одночасною високою дисциплінованістю, розумна ініціативність, цілеспрямованість у досягненні мети, креативність, тобто здатність до нестандартного, оригінального і швидкого мислення та поведінки, здатність находити неочікувані рішення у, здавалося б, безвихідній ситуації, не втрачаючи при цьому самовладання, а часто і гумору. Важливими для організаторів медсестринської справи є $\mathrm{i}$ такі якості, як уміння планувати, аналізувати, бути готовим до ризику, знаходити компромісні рішення, передбачати виникнення різних ситуацій та виробляти стійкість до стресів. Цьому сприятимуть проведення відеоігор, рольових та ділових ігор з удосконалення комунікативних навичок, вироблення стилю керівництва підлеглим персоналом тощо. 
Весь накопичений досвід необхідно відтворювати у нових сучасних підручниках та посібниках, для чого необхідно створювати колективи авторів, як це ввійшло у практику в Тернопільського державного медичного університету імені І. Я. Горбачевського, до складу яких обов'язково повинні входити магістри медсестринства. Це зумовлено тим, що для медсестер випущено вже немало навчальних підручників та посібників, багато 3 них на достатньо хорошому рівні. Але майже всі вони мають один суттєвий недолік - на тлі добре викладених теоретичних даних не враховано суттєвих деталей алгоритму виконання маніпуляцій, які повинна виконувати медсестра під час роботи у спеціалізованому відділенні. Причиною цього якраз і $\epsilon$ те, що у колективах авторів наявні тільки лікарі, які просто не можуть знати усіх нюансів роботи медсестринського персоналу. На жаль, дуже часто медсестри вчаться на своїх помилках, значну частину 3 яких можна було б уникнути за умови детально викладеного та проілюстрованого навчального матеріалу. Добре було б доповнити його створенням серій навчальних відеофільмів з виконання практичних маніпуляцій з урахуванням специфіки роботи у кожному з відділень чи кабінетів. Такі відеофільми з оволодіння практичними навичками уже створені і продовжують створюватися у нашому університеті.

Необхідно також вирішувати питання щодо удосконалення та навчання медсестер-магістрів протягом усього професійного життя. Розуміння складності змін, які безперервно відбуваються у сестринській справі, а також сприйняття сестринської справи як самостійної унікальної професії, сприяє тому, що ба- гато медсестер вже усвідомлює необхідність безперервної освіти протягом всього життя, сенс якого полягає в тому, що людина може і повинна бути відкритою для нових ідей, рішень, навичок або моделей поведінки у будь-якому віці. Знань і навичок, яких медсестра набуває в університеті (інституті, коледжі), більше не достатньо для успішної професійної кар'єри навіть протягом одного десятиліття. Концепція “навчання протягом всього життя” властива багатьом професіям, проте для медсестер вона є особливо актуальною.

Висновки. Розвиток дистанційної освіти в Україні на сьогодні відповідає вимогам до інформаційного суспільства, що прагне інтегруватись у європейську і світову спільноту. Кількість студентів та слухачів, що здатні і бажають навчатись за дистанційними технологіями, вже зараз досить велика і зростає дуже швидко.

Очікувані позитивні наслідки створення системи дистанційної освіти для магістрів медсестринства в Україні:

• розширення кола споживачів освітніх послуг, у тому числі у важкодоступних, малонаселених регіонах, у районах, віддалених від наукових і культурних центрів України;

- підвищення якості навчання слухачів та студентів незалежно від їхнього місцезнаходження;

- створення додаткових робочих місць для громадян України;

- можливість одержання освіти за українськими програмами громадянам зарубіжних країн;

- реалізація системи безперервної освіти “через все життя";

• індивідуалізація навчання при масовості освіти.

\section{Лiтература}

1. Про затвердження Положення про дистанційне навчання : наказ МОН України № 40 від 21.01.2004 p. // Офіційний вісник України. - 2004. - № 15. - С. 241-253.

2. Денисов Д. О. Дистанційна освіта в Україні/ Д. О. Денисов // Актуальні питання дистанційної освіти, порівняння сучасного стану дистанційної освіти в Україні та країнах Західної Європи : зб. наук. праць : у 2 ч. - Суми, 2004. - Ч. 1: Педагогіка та методика навчання і виховання. - С. 44-48.

3. Банчук М. В. Сучасні завдання вищої медичної школи / М. В. Банчук, О. П. Волосовець, Т. І. Чернишенко // Магістр медсестринства. -2008. - № 1.-С. 17-21.

4. Дистанційна освітаяк новітній підхід до ступеневої підготовки медичних сестер / Л. Я. Ковальчук, О. І. Яшан,

С. О. Ястремська, С. О. Коноваленко // Медсестринство. 2010. - № 1.-C. 5-6.

5. Коноваленко С. О. Необхідність, проблеми та наслідки створення системи дистанційної освіти в Україні / С. О. Коноваленко, В. В. Максимова // Медсестринство.2010. - № 2. - C. 8-11.

6. Максимова В. В. Щодо проблемних питань з розвитку медсестринства в Україні / В. В. Максимова, С. О. Ястремська// Медсестринство. - 2009. - № 3. - С. 15-19.

7. Дистанційна форма навчання в медсестринстві-перший результат впровадження / С. О. Ястремська, О. С. Усинська, І. Я. Господарський, Н. І. Рега // Медсестринство. -2011 . - № 3. - С. 8-9. 